\title{
Negatividade e Positividade da Política em Marx: A partir das Glosas Críticas Marginais
}

Vilson da Mata $^{1}$

\section{Resumo}

A partir da análise imanente ao texto: Glosas Críticas Marginais ao Artigo "O Rei da Prússia e a Reforma Social". De um Prussiano, este artigo pretende contribuir para a discussão a respeito da política e do Estado em Marx. Entendida em seu duplo caráter (negatividade e positividade) a política democrático burguesa é analisada, pelo autor alemão, como expressão da sociedade civil moderna, na qual particularidade individual e universalidade social estão cindidas. Para Marx, o Estado não é anterior à sociedade, mas o contrário e, neste pormenor, o texto marca o rompimento do autor alemão com os hegelianos de esquerda. Marx deixa claro que o Estado capitalista é a expressão de uma sociedade em que a desigualdade e as misérias sociais não podem ser superadas, senão na superação do próprio Estado. Neste texto de juventude de Marx encontram-se, já, os conceitos marxianos de alienação, emancipação, revolução e comunismo.

Palavras Chave: Marxismo - Política - Estado - Revolução

\section{Negativity and Positivity of the Politics in Marx: From the Glosas Críticas Marginais}

\section{Summary}

From the analysis of the immanent to the text: Glosas Críticas Marginais ao Artigo "O Rei da Prússia e a Reforma Social". De um Prussiano, this article intends to contribute to the discussion concerning the politics and the State in Marx. Understood in its double character (negativity and positivity) the bourgeois democratic politics is analyzed, by the German author, as an expression of the modern civil society, in which the individual particularity and social universality are divided. To Marx, the State is not prior to society, in truth it is the contrary and, in detail, the text highlights the breach of the German author with the Hegelian of the left. Marx makes it clear that the capitalist State is the expression of a society in which the inequality and the social miseries cannot be overcome, save for the overcoming of the State itself. In this text of Marx youth are already found the Marxist concepts of alienation, emancipation, revolution and communism.

Key Words: Marxism - Politics - State - Revolution

\footnotetext{
${ }^{1}$ Doutor em Educação pela Universidade Federal do Ceará - UFC e professor adjunto da Universidade Federal do Paraná - UFPR
} 
Introdução

Glosas Críticas Marginais ao Artigo "O Rei da Prússia e a Reforma Social. De um Prussiano" é um texto pouco conhecido de Marx. Escrito em 1844, foi publicado em duas partes no jornal Worwäts! (periódico de esquerda do qual Marx era colaborador) $\mathrm{n}^{\circ} \mathrm{s} 63$ e 64 , ambos de agosto daquele ano. Embora desconhecido pela maioria, trata-se de um escrito contemporâneo a outras obras notórias do pensador alemão, como os Manuscritos Econômico-Filosóficos, A Sagrada Família, Sobre a Questão Judaica e A Ideologia Alemã.

Trata-se de um artigo no qual Marx sintetiza, claramente, sua crítica à política democrático burguesa, ao Estado e à sociedade civil. É um texto seminal, em que o autor apresenta seu pensamento em statu nascendi, em pleno embate contra as concepções metafísicas do Estado, expressas pela filosofia hegeliana tal como apresentada pelos neohegelianos, notadamente os de esquerda.

É o neo-hegeliano Arnold Ruge* o autor do artigo O Rei da Prússia e a Reforma Social. De um prussiano, objeto das glosas que Marx compõe, primeiro, por discordar das teses ali apresentadas, principalmente a de que a falta de intelecto político dos alemães os tornaria incapazes de compreender a dimensão universal dos acontecimentos particulares. $\mathrm{O}$ acontecimento particular que motiva o artigo de Ruge é a revolta dos tecelões da Silésia, violentamente reprimida pelo Estado Prussiano. Nas palavras de Ivo Tonet: "Marx faz uma dura crítica às ideias de Ruge e aproveita para explicar a sua posição quanto ao um conjunto de questões da mais alta importância e que farão parte do núcleo central de sua nova proposta teórico-prática" (Tonet, 2010, p. 8).

Em segundo lugar, Frederico (2009) esclarece que Marx viu a necessidade de responder ao artigo de Ruge porque este era saxão. Marx era prussiano de nascimento e, receoso de que o epíteto do título do artigo dirigisse a atenção para ele, além do fato de que suas divergências com Ruge acentuavam-se, tratou de marcar de modo claro seu ponto de vista diverso daquele contido no texto do "prussiano" Ruge. Conforme Frederico:

O pessimismo de Ruge sobre as possibilidades de uma revolução na Prússia levou-o a aproximar-se do ideário liberal e à crença na educação e instrução como os melhores instrumentos para a emancipação humana. Marx, por outro lado, apostava num projeto revolucionário que, rapidamente, transitou da perspectiva democrática radical para o comunismo (Frederico, 2009, p. 111).

\footnotetext{
*Amigo e colaborador de Marx nos Anais Franco Alemães (Konder, 1981, p. 35).
} 
A atualidade deste pequeno texto de Marx reside no desnudamento das vicissitudes, particularidades e problemas da política democrático burguesa. A partir dos elementos constituintes do intelecto político, Marx foi capaz de demonstrar sua insuficiência para a superação das desigualdades sociais, mas também a importância da política, numa perspectiva mais ampla, como instrumento de transformação.

Fica exposto o duplo caráter da política em Marx, que nega de fato a política em sua expressão particular, determinada e limitada na sociedade capitalista. Contudo, a política como dimensão da existência humana não só é reafirmada, como não pode ser ignorada como elemento constituinte da própria civilização humana e da formação do indivíduo.

Negatividade e positividade formam o caráter práxico da política no texto marxiano e é neste ponto que a atualidade das Glosas Críticas revela-se como um farol que, desde o século XIX, lança luz sobre os complexos atóis das importantes questões que a política suscita para os nossos dias, como, por exemplo, o papel do Estado em uma sociedade capitalista e a questão da emancipação.

Para o artigo aqui apresentado, três pontos do texto marxiano são abordados. Primeiro, a negatividade da política e a impossibilidade de superação das desigualdades sociais a partir da administração e do assistencialismo de Estado. Segundo, a crítica dos limites da política democrático burguesa, compreendendo sua parcialidade e a estrutura contraditória do Estado e, por fim, apontamentos sobre a positividade da política, em uma perspectiva mais ampla, como instrumento para a transformação social, para a emancipação humana.

\section{Sociedade civil, Política e Estado, ou, a negatividade da política}

O artigo de Arnold Ruge criticando o Estado prussiano apresenta a tese segundo a qual a relação geral entre a política e os males sociais estava associada ao fato de que o intelecto político, por um ato de vontade, seria capaz de suprimir as desigualdades sociais. $\mathrm{Na}$ Alemanha isso ainda não havia ocorrido em função de o Estado encontrar-se em um estágio inferior, quando comparado com os países politicamente mais avançados, notadamente Inglaterra e França.

O atraso em relação aos países europeus estaria expresso na não separação, na Alemanha, entre Estado e religião. A política e o Estado modernos (democracia 
representativa, Estado de Direito e liberdade de expressão) não efetivados, levariam ao assistencialismo como solução para atenuar as desigualdades sociais. Esse atraso impediria o intelecto político de compreender a miséria social como um dano universal à sociedade e não apenas como particularidade dos miseráveis. A conclusão a que Ruge chega, então, é de que o atraso alemão em termos de intelecto político seria o culpado pela concepção segundo a qual a causa do pauperismo, das desigualdades sociais, seria uma falha administrativa e de assistência do Estado. Para o "prussiano", os fatores burocráticos determinam a pobreza.

Marx refuta as afirmações de Ruge. A relação geral entre política e desigualdades sociais não pode ser uma questão de vontade política. As circunstâncias objetivadas historicamente impedem que a vontade política se efetive, oferecendo um conjunto de soluções bastante limitado para enfrentar os problemas sociais. Não é o atraso político da Alemanha, mas a própria estrutura do Estado, que impede a superação dos problemas sociais. Também não se pode aceitar a tese de que a pobreza e a miséria sejam males próprios de países não desenvolvidos. Quando o Estado está fundado sobre as bases da propriedade privada, da exploração do trabalho, da geração de lucro, o pauperismo é sua conseqüência necessária, não importando o quão desenvolvido é o país.

O exemplo utilizado por Marx é a Inglaterra, nação mais avançada politicamente no século XIX. Ali havia instituições políticas avançadas e maduras, e também o pauperismo: Marx lembra que o pauperismo dos trabalhadores na Inglaterra não era parcial, mas universal, não se limitava aos distritos industriais, mas se estendia a todos os trabalhadores. Nos países mais desenvolvidos econômica e politicamente, o pauperismo é um problema inevitável que nenhuma vontade política é capaz de suprimir. O entendimento, na Inglaterra, também era de que a política seria a responsável pela superação das desigualdades sociais, atribuindo suas causas à atuação do partido adversário: "nenhum dos partidos encontra a causa na política geral; ao contrário, cada um deles a encontra na política do partido adversário, porém, ambos os partidos sequer sonham com uma reforma da sociedade”. (Marx, 2010, p. 48).

Assim como na Alemanha, o Estado inglês concebe a miséria social como causada pela vontade política e polariza a responsabilidade dentro da própria estrutura do Estado burguês, culpando o partido da oposição. A estrutura da própria organização social não é questionada e o problema é tratado como uma abstração. Nas palavras de Chagas:

Assim, onde quer que existam partidos políticos, cada um deles encontra a razão de todo mal não no Estado, mas no partido adversário. Até os partidos críticos e

\begin{tabular}{|l|l|l|l|l|}
\hline Q Ronista Dialectus & Ano 2 & n.5 & Agosto - Dezembro 2014 & p. 80 - 96 \\
\hline
\end{tabular}


emancipadores procuram o fundamento do mal social não na essência do Estado, mas numa determinada forma de governo, que buscam substituir por outra (Chagas, 1998, p. 67).

Nesta concepção, cabe ao indivíduo particular progredir, pelo trabalho, a fim de superar sua condição miserável. Para tanto, a educação, na concepção burguesa, é o caminho mais seguro. Seria então a falta de formação e cultura do trabalhador o motivo fundamental de sua condição miserável. Por não entender as leis que regem a sociedade, o trabalhador não é capaz de ascender socialmente e, por sua ignorância, promove rebeliões. $\mathrm{O}$ fracasso em remediar a miséria é, então, causado pela má educação dos trabalhadores. Tal concepção, idealizada, encobre a expressão mais perversa da "falta de educação" do trabalhador. Pela exploração do trabalho em suas minas de carvão, fábricas e ferrovias, a Inglaterra obrigou homens, mulheres e crianças a jornadas desumanas de trabalho, impossibilitando-lhes o ingresso em instituições de ensino, que, além de serem poucas no século XIX, eram caras. A própria burguesia cultivou, pela exploração do trabalho quase escravo, a miséria e a ignorância do trabalhador desde a sua infância. Em um rasgo idealista, atribui à não educação do trabalhador sua inabilidade para lidar com a própria miséria.

Marx quer mostrar que não importa o nível de avanço do Estado de direito burguês e da democracia representativa, o único modo de justificar a permanência do pauperismo é considerá-lo como falha administrativa ou de assistência. Instituída pela legislação, a assistência do Estado procura oferecer consolo aos mais necessitados. Porém, trata-se de uma medida paliativa, posto que não ataque o fundamento da miséria (propriedade privada, exploração do trabalho), não tendo, portanto, possibilidade alguma de eliminar a miséria.

A caridade do Estado é o meio legal contra o mal social, mas incapaz de combatê-lo e exterminá-lo porque a política burguesa não extermina as causas objetivas da pobreza e nem de longe abala as estruturas da própria sociedade capitalista, ela só ataca efetivamente a expressão mais imediata do problema. O fracasso da caridade social pela via administrativa leva ao desvelamento da faceta mais perversa da mentalidade política: se a administração falha e a assistência é insuficiente, então, a responsabilidade pela miséria e a pobreza é atribuída ao próprio trabalhador. Apesar das medidas administrativas (leis, repressão, impostos), o pauperismo não deixou de avolumar-se.

$\mathrm{O}$ assistencialismo de Estado favorece o crescimento do problema na medida em que não combate as causas da miséria social, mas apenas sua expressão imediata. Não havendo 
solução, dentro do Estado burguês, para o problema do pauperismo, este passa a ser considerado como uma lei da natureza. Se, como afere a teoria Mauthusiana, o aumento da população tende a superar os meios de subsistência, e na medida em que é uma lei "natural" da sociedade humana, então o pauperismo e a miséria são decorrências "naturais" e necessárias, agravadas pela desídia dos trabalhadores. Culpado pela sua miséria e pelos males sociais decorrentes dela, passa o trabalhador a ser reprimido e punido pela via administrativa: não obtendo sucesso nem através da assistência oficial ou das medidas administrativas, o Estado então entende que a punição do pobre é uma forma de discipliná-lo:

\begin{abstract}
A lição geral que a política da Inglaterra tirou do pauperismo se limita ao fato de que, no curso do desenvolvimento, apesar das medidas administrativas, o pauperismo foi configurando-se como uma instituição nacional e chegou por isso, inevitavelmente, a ser objeto de uma administração ramificada e bastante extensa, uma administração, no entanto, que não tem mais a tarefa de eliminá-lo, mas, ao contrário, de discipliná-lo e eternizá-lo. (Marx, 2010 p. 54).
\end{abstract}

Renunciando ao combate das bases do pauperismo, a administração do Estado burguês encontra a solução paliativa na repressão policial. Impotente que é para eliminar a causa das desigualdades sociais, o Estado então se dedica a discipliná-la e reprimi-la, a mantendo dentro das possibilidades de controle. E por que o Estado deve manter controle e vigilância sobre a pobreza? Entre outras coisas, para evitar que os pobres e miseráveis rebelem-se contra sua condição sub-humana; mas também para evitar a "desagradável” visão da miséria espalhada pelas ruas e praças de suas cidades. "Aquilo que, no começo, fazia-se derivar de uma falta de assistência, agora se faz derivar de um excesso de assistência. Finalmente, a miséria é considerada como culpa dos pobres e, desse modo, neles punida”. (Marx, 2010, p. 54).

Sendo os pobres culpados pela própria miséria, torna-se caso para o braço armado do Estado administrar, como diz Marx, com “ternura policial”, sempre que o pauperismo ameaça transbordar para os recantos oficiais da sociedade civil (invasões, ocupações, protestos). Esta é uma fratura existente na sociedade moderna que Marx identifica: tanto os países atrasados quanto os mais avançados politicamente entendem o problema do pauperismo pela via administrativa. Tratada como problema de gestão, a ação contra o pauperismo é pontual e assistencialista, incapaz de resolver efetivamente a questão.

É a estrutura da sociedade, e não a política, a causa da miséria. Não há medida administrativa que seja capaz de "melhorar" ou humanizar a sociedade capitalista, posto que o problema supera as possibilidades da vontade política. $\mathrm{O}$ pauperismo não pode ser resolvido

\begin{tabular}{|l|l|l|l|l|}
\hline Q Rovista Dialectus & Ano 2 & n.5 & Agosto - Dezembro 2014 & p. 80 - 96 \\
\hline
\end{tabular}


pela administração e/ou assistencialismo, nem pela política burguesa, porque não abala nem questiona as bases das desigualdades. "O Estado não pode eliminar a contradição entre a função e a boa vontade da administração, de um lado, e os seus meios e possibilidades, de outro, sem eliminar a si mesmo, uma vez que repousa sobre essa contradição”. (Marx, 2010, p. 60). E qual a origem dessa contradição?

A sociedade civil e o Estado modernos são essencialmente diferentes da sociedade civil e do Estado pré-modernos. Na sociedade Antiga e Medieva, indivíduo e Estado não se separavam, por um lado, e Estado e Religião eram ligados, por outro. Nas sociedades pré modernas, sociedade civil e política não se separam. Na Antiguidade, o indivíduo encontra sua plena realização humana na subserviência ao Estado. Nenhum grego acreditava ser possível a vida civilizada fora da Cidade Estado, a Polis não é apenas uma cidade murada que protege contra os bárbaros incivilizados, ela é o conceito do qual emana toda noção de humanidade e civilidade do homem antigo. Pode-se dizer que a sociedade civil é uma extensão do indivíduo, e que o Estado é o próprio braço político do corpo social. Com a dissolução da sociedade Antiga e Medieva e a constituição da sociedade moderna, a relação entre sociedade civil e Estado transformou-se profundamente.

$\mathrm{Na}$ modernidade a sociedade civil individualizou-se e, na sua autodeterminação individual, tornou-se apolítica. Estado e sociedade civil, separados, constituem-se na expressão do indivíduo atomístico e particular, auto-determinado e alienado de suas relações com a totalidade social à qual pertence e que lhe determina o ser, em que o interesse particular é expresso por uma política representativa. No campo desta política representativa, chamada de democrática, os indivíduos são considerados iguais na esfera formal, porém, esta igualdade não se realiza na sociedade real, posto que no capitalismo a geração de lucro e riquezas, a partir da iniciativa particular, está na base da própria organização social. Na política capitalista, a igualdade é uma representação fantasiosa e não resolve os problemas reais, mas os reafirma e conserva.

O indivíduo particular e auto-determinado, independente de obrigações mais amplas com o Estado e livre para negociar com os outros indivíduos constitui-se como o arquétipo do homem ideal da modernidade. A sociedade civil torna-se o conjunto das ações dos indivíduos isolados e atomizados que objetivam unicamente a satisfação dos seus interesses particulares. Na sociedade moderna, a participação política saiu da vida da sociedade civil (a não ser, talvez, no momento de depositar um solitário voto na urna). Quer seja pelo caráter egoísta e 
auto-determinado do indivíduo moderno ou pela complexificação do Estado, a participação política do homem moderno, que se considera livre e emancipado, reduziu-se a um mínimo tão insignificante que não é mais capaz de influir nos destinos do Estado.

Separado da sociedade civil, sem um ethos, o Estado surge como a instância de resolução de todos os problemas, mas apenas o faz formalmente, parcialmente e pontualmente, pois não tem condições de combater os problemas sociais em sua totalidade. É uma política separada da sociedade, uma política localizada na esfera da formalidade, que "repousa sobre a contradição entre vida privada e pública, sobre a contradição entre os interesses gerais e os interesses particulares". (Marx, 2010, p. 60).

Entretanto, o Estado é profundamente dependente da sociedade civil, pois só encontra razão de existência no seu caráter liberal de administrador das iniciativas particulares. Como instância da universalidade, fica reduzido e refém da particularidade. A esfera do Estado é dependente da esfera privatista da iniciativa particular e, por isto, a participação política tornase duplamente isolada: primeiro, porque expressa exclusivamente o interesse privado, fragmentário, pois é incapaz de entender universalmente a sociedade; segundo, a política isolou-se da sociedade civil, que tornou-se apolítica, amorfa e atomística. A política refugiouse nas engrenagens burocráticas do Estado e, tal qual engrenagens mesmo, realiza o movimento simples, contínuo e repetitivo da administração e da assistência.

O Estado não existe para solucionar as desigualdades sociais como o pauperismo e a miséria, mas para legitimar uma sociedade ilegítima, é dele a função de garantir a propriedade privada, a iniciativa particular e o mercado. "Mais ainda: frente a conseqüências que brotam da natureza antissocial dessa vida civil, dessa propriedade privada, desse comércio, dessa indústria, dessa rapina recíproca das diferentes esferas civis, frente a estas conseqüências, a impotência é a lei natural da administração". (Marx, 2010, p. 60). Não podendo fazer mais que assistencialismo ou medidas administrativas, a culpabilização do trabalhador serve como argumento contra a pobreza e a miséria e se torna abandono à própria sorte, criando cidadãos com igualdade jurídica, mas desigualdade real.

Contudo, para Marx (2010), Estado e sociedade civil não se constituem como instâncias diferentes. O Estado é a esfera organizadora da sociedade civil. Nele estão impressas todas as contradições presentes nesta. Este é um ponto importante: em Marx, o Estado é dependente da sociedade civil, não o contrário. Neste aspecto, assim como em tantos outros, o autor alemão expõe uma ruptura com a tradição filosófica. Desde Platão até Hegel, a 
essência e a missão do Estado são objeto de reflexão na tentativa de definir seu papel para o indivíduo e para a sociedade. O Estado é tido como insubstituível, necessário, independente.

Marx inverte esse entendimento e esclarece a dependência do Estado em relação à sociedade civil. De um lado, não é o Estado a esfera que inventa a sociedade civil, mas o contrário: a sociedade civil se organiza e se torna mais complexa, necessitando inventar o Estado, que a representa, organiza e expressa; de outro lado, por ser dependente da sociedade civil, o limite do Estado é exatamente o da visão organizativa, administrativa:

O Estado e a organização da sociedade não são, do ponto de vista político, duas coisas diferentes. O Estado é o ordenamento da sociedade. Quando o Estado admite a existência de problemas sociais, procura-os ou em leis da natureza, que nenhuma força humana pode comandar, ou na vida privada, que é independente dele, ou na ineficiência da administração, que depende dele. (Marx, 2010, p. 59).

Ora, se a atividade organizadora é a função do Estado inventado pela sociedade civil, então seu limite de compreensão dos problemas sociais é haver defeitos de administração. Quando a sociedade civil torna-se um conjunto de indivíduos isolados, atomísticos, apolíticos e a política fica confinada à esfera do Estado, então ela se torna tecnocrática, burocrática, assistencialista e impotente para combater e exterminar os males sociais. "Por isso, a administração deve limitar-se a uma atividade formal e negativa, uma vez que exatamente lá onde começa a vida civil e o seu trabalho, cessa o seu poder”. (Marx, 2010, p. 60).

Fica estabelecida, assim, uma contradição fundamental entre Estado e sociedade civil. Esta atribui àquele a função administrativa de resolução dos males sociais que, contudo, não podem ser superados porque o Estado constitui-se como expressão da sociedade civil. "O Estado não pode eliminar a contradição entre a função e a boa vontade da administração de um lado, e os seus meios e possibilidades, de outro, sem eliminar a si mesmo, uma vez que repousa sobre essa contradição" (Marx, 2010, p. 60). O Estado não age contra a pobreza e a miséria e nem pode, pois está a serviço do capital. Não pode abrir mão do assistencialismo, porque o capital abrevia a vida, ludibria a inteligência, deteriora a consciência, brutaliza o corpo e deprime a auto-realização humana. Em uma sociedade assim, é preciso desenvolver dispositivos que minimizem os efeitos danosos da propriedade privada.

As possibilidades de superação da pobreza estão na superação da propriedade privada. Para tanto, o Estado teria de ser capaz de superar a contradição entre interesses particulares e interesses gerais. Superar tal contradição significaria o fim do Estado. Portanto, a escravidão 
legitimada pelo trabalho assalariado na modernidade não pode ser combatida pelo Estado que, para acabar com sua impotência teria de eliminar a si mesmo. Nas palavras do próprio Marx:

\begin{abstract}
Se o Estado moderno quisesse acabar com a impotência da sua administração, teria de acabar com a atual vida privada. Se ele quisesse eliminar a vida privada, deveria eliminar a si mesmo, uma vez que ele só existe como antítese dela. Mas nenhum ser vivo acredita que os defeitos de sua existência tenham a sua raiz no princípio de sua vida, na essência de sua vida, mas, ao contrário, em circunstâncias externas à sua vida. O suicídio é contra a natureza. Por isso, o Estado não pode acreditar na impotência interior da sua administração, isto é, de si mesmo. Ele pode descobrir apenas defeitos formais, casuais, da mesma, e tentar remediá-los. Se tais modificações são infrutíferas, então o mal social é uma imperfeição natural, independente do homem, uma lei de Deus, ou então a vontade dos indivíduos particulares é por demais corrupta para corresponder aos bons objetivos da administração. (Marx, 2010, p. 61).
\end{abstract}

Para superar as desigualdades sociais, o Estado teria de suprimir a contradição entre interesses privados e públicos. Isto significaria negar uma sociedade cuja característica imanente é a satisfação do interesse individual, da iniciativa privada. Ainda que defenda a igualdade, o Estado capitalista alimenta a desigualdade. A defesa da igualdade pelo Estado é atividade puramente formal e negativa. O poder não é capaz de intervir na vida civil. Onde começa a sociedade civil, cessa o poder do Estado.

Os problemas sociais então não se originam na má administração e/ou na burocracia, mas na estrutura da sociedade do capital. O assistencialismo de Estado embota as vistas para as questões basilares da superação do pauperismo: a propriedade privada, a exploração do trabalho, a luta de classes. Considerar o problema como defeito de administração e de assistência é considerá-lo em sua parcialidade. A essência da sociedade moderna é tentar resolver os problemas em sua parcialidade.

Quando falham os mecanismos da política, a culpabilização do pobre por sua ignomínia e a criminalização do pauperismo na forma de leis contra a mendicância ou "vagabundagem" são dispositivos que somente as mentalidades políticas mais avançadas podem inventar. Por isso, o Estado mais avançado e poderoso será exatamente aquele que menos probabilidade terá de compreender os males sociais como determinação estrutural de uma sociedade desigual. O limite do intelecto político está justamente em pensar os problemas sociais nos limites da política.

Quanto mais poderoso é o Estado e, portanto, quanto mais político é um país, tanto menos está disposto a procurar no princípio do Estado, portanto no atual ordenamento da sociedade, do qual o Estado é a expressão ativa, autoconsciente e 
oficial, o fundamento dos males sociais e a compreender-lhes o princípio geral. $\mathrm{O}$ intelecto político é político exatamente na medida em que pensa dentro dos limites da política. [...] O princípio da política é a vontade. Quanto mais unilateral, isto é, quanto mais perfeito é o intelecto político, tanto mais ele crê na onipotência da vontade e tanto mais é cego frente aos limites naturais e espirituais da vontade e, consequentemente, tanto mais é incapaz de descobrir a fonte dos males sociais. (Marx, 2010, p. 62).

Quanto mais poderoso é o Estado, quanto mais desenvolvido está o capital, menos é capaz de compreender o fundamento das desigualdades que ele próprio engendra. É bastante claro que o modelo de Estado, tal como existente, não é capaz de combater problemas sociais: nos países mais desenvolvidos do mundo atual, a miséria e a pobreza continuam crescendo e atingiram seu mais elevado nível. O aspecto negativo da política em Marx, como reforçadora e administradora da sociedade burguesa, é absolutamente atual e candente.

\section{Crítica dos limites da política burguesa}

Em Marx, a superação da alienação, a emancipação humana, não são conquistadas pelo modelo atual. Na sociedade moderna a política deslocou-se da sociedade civil para a esfera do Estado. Mas fazer política é necessário, até para exigir do Estado que ações contra ele mesmo sejam implementadas. A superação da negatividade da política burguesa não está em tomá-la como problema administrativo e assistencial, mas de desconstruí-la a fim de enfrentar as contradições do capital. Deste modo, $\mathrm{O}$ autor alemão nega a política em seu modelo moderno, burguês e representativo, em que o seu conteúdo afastou-se do mundo real e da sociedade civil. A vida real tornou-se apolítica e a política foi instalada no mecanismo do Estado burguês.

O limite fundamental do pensamento político é, exatamente, ser pensamento político, pois só pensa dentro dos limites da política. Quanto mais avançado o pensamento político, tanto maior sua miopia para os males sociais, uma vez que só consegue entendê-los a partir de dentro de sua própria estrutura. E qual é o princípio fundamental da política? A vontade. Mas a vontade é unilateral, é desejo de potência e busca pelo poder de realização. Sendo unilateral, crê no poder supremo da vontade até o limite em que a vontade de um indivíduo se sobreponha a todos os demais, porém, permanece incapaz de constatar a fonte e a origem dos problemas sociais. O intelecto político enxerga a vontade do indivíduo como capaz de emancipar na exata medida em que sua consciência política individual se engrandece. Para o

\begin{tabular}{|l|l|l|l|l|}
\hline Q Ropista Dialectus & Ano 2 & n.5 & Agosto - Dezembro 2014 & p. 80 - 96 \\
\hline
\end{tabular}


pensamento político, a capacidade cultural é a condição para a emancipação política. Por emancipação política não se deve entender o abrandar das desigualdades sociais, mas a busca pela substituição de um modelo de Estado por outro. Complementa Marx:

\begin{abstract}
Quanto mais evoluído e geral é o intelecto político de um povo tanto mais o proletariado - pelo menos no início do movimento - gasta suas forças em insensatas e inúteis revoltas sufocadas em sangue. Uma vez que ele pensa na forma política, vê o fundamento de todos os males na vontade e todos os meios para remediá-los na violência e na derrocada de uma determinada forma de Estado. (Marx, 2010, p. 74).
\end{abstract}

O intelecto político torna enevoada a visão das desigualdades sociais, falseia o conhecimento, não só do Estado, mas também daqueles que lutam contra o Estado burguês. Esta visão deficitária, esse olhar míope, faz parecer que a miséria cria um intelecto miserável. A miséria e a pobreza seriam então seus próprios algozes na medida em que provém delas um intelecto político incapaz de descobri-las e superá-las. Marx corrige esta concepção demonstrando que não é a miséria e a pobreza que criam o intelecto político, mas, ao contrário, é o bem estar. "O intelecto político é um espiritualista e é concedido a quem já possui e desfruta das comodidades". (Marx, 2010, p. 73). Sendo proveniente das classes que já desfrutam de comodidades, o intelecto político não descobre a miséria e não é capaz de pensar nela fora dos limites da própria política. Portanto, não é a falta de cultura dos pobres que encaminha uma política pobre, mas a imposição dos interesses de classe é que gera uma expressão da política, assistencialista e de cunho técnico-administrativo, que encontra eco na pobreza, que, por sua vez, não é culpa do pobre, mas da estrutura da propriedade privada, na qual se baseia a sociedade capitalista.

A superação da pobreza e da miséria política, entendida como emancipação, é parcial, insuficiente e incompleta, pois é apenas emancipação política de uma estrutura de Estado. A superação da miséria humana não pode ser completa sem a superação da totalidade da forma societária sobre a qual se fundam os princípios da propriedade privada, da divisão do trabalho, da exploração pela mais valia, do trabalho abstrato ${ }^{2}$. Para Marx, o Estado moderno não é uma comunidade livre, universal ou voltado para o bem comum, mas é fundado na exploração do trabalho. Uma sociedade de contradições, de conflito de classes, de exploração do trabalho,

\footnotetext{
${ }^{2}$ Na segunda parte das Glosas Críticas Marginais, Marx aborda um tema de fundamental importância: o isolamento dos homens da comunidade, que o Estado, pretensamente, deveria representar e manter coesa. Esta questão é essencial, pois dela emanam já as primeiras considerações sobre a alienação, que Marx irá aprofundar e sistematizar em um texto contemporâneo ao Glosas, que, porém, só ganhou publicação no século XX: Manuscritos Econômico-Filosóficos de 1844. Neste artigo os Manuscritos não serão analisados, por uma questão de espaço e de objetividade.
} 
não pode legitimar um Estado que se ocupe do bem da comunidade, mas apenas da desigualdade, da violência e da propriedade privada. A sociedade civil moderna é atomizada em indivíduos cuja principal atividade é a busca pela satisfação de interesses egoístas e narcísicos. Contraditoriamente, embora cada indivíduo busque isoladamente a satisfação de suas necessidades, é na comunidade, na associação e cooperação com outros indivíduos que se encontra a saciedade das necessidades. É para que haja alguma harmonia que se erguem instituições como o Direito, a Política e, evidentemente, o Estado.

A estrutura do Estado é então desenvolvida para que haja harmonia relativa entre as necessidades individuais e os interesses coletivos. E a harmonia é relativa porque a função do Estado é, pela administração, perpetuar as relações sociais burguesas. No caso do Estado burguês, a divisão dos poderes (executivo, judiciário e legislativo) importa menos que a direção para a qual todos eles apontam: a garantia da permanência da propriedade privada e a repressão de tudo aquilo que a ameace. Desta maneira, quando a lei afirma que todos os homens são iguais, trata-se meramente de uma igualdade formal, posto que nenhum dos poderes constituídos seja capaz de garantir seu cumprimento.

\section{A Transformação Social e a Emancipação Humana, ou, a Positividade da Política}

Na sua análise das Glosas Críticas, Chagas indaga se o Estado "teria condições ou não de proceder de outra forma (1998, p. 67). Sintetizando uma resposta, explica que na sociedade capitalista o ser humano pertence a uma comunidade ilusória, porque só existe na formalidade do Estado burguês (essa comunidade), que legitima uma sociedade ilegítima, baseada na exploração do trabalho, empobrecendo o trabalhador não só materialmente, mas também espiritualmente, isolando-o da comunidade política.

Marx entende que o Estado burguês não é capaz de garantir relações políticas de igualdade, posto que se constitua como uma comunidade de indivíduos que se relacionam a partir de frágeis laços de necessidade, além de estarem, os indivíduos, em completo isolamento em relação à totalidade dessa comunidade. Portanto, não é possível ao Estado burguês proceder de modo diferente, pois a realidade que efetiva é aquela na qual a classe que detém o poder econômico assegura o poder político, restringindo até o limite os direitos da classe trabalhadora. Torna-se então o trabalhador um ser pobre e miserável, isolado de sua própria vida. Afirma Marx: 


\begin{abstract}
Mas a comunidade da qual o trabalhador está isolado é uma comunidade inteiramente diferente e de uma outra extensão que a comunidade política. Essa comunidade, da qual é separado pelo seu trabalho, é a própria vida, a vida física e espiritual, a moralidade humana. A essência humana é a verdadeira comunidade humana. E assim como o desesperado isolamento dela é incomparavelmente mais universal, insuportável, pavoroso e contraditório do que o isolamento da comunidade política, assim também a supressão desse isolamento e até uma reação parcial, uma revolta contra ele, é tanto mais infinita quanto infinito é o homem em relação ao cidadão e a vida humana em relação à vida política. (Marx, 2010, p. 75$6)$.
\end{abstract}

O isolamento do trabalhador é uma decorrência da comunidade falsa preconizada pela política e pelo Estado, que só podem garantir uma comunidade formal em que igualdade e liberdade não se efetivam, mas, ao contrário, distanciam-se do trabalhador. E não se efetivam porque onde uma classe detém o poder político e econômico, lança mão de tais poderes a fim de perpetuar a exploração. Com isto, o trabalhador explorado encontra-se estranhado de sua essência, que é o próprio trabalho. O próprio produto do trabalho impõe-se ante o trabalhador como algo estranho e independente dele. Ao não se reconhecer naquilo que é sua atividade vital, o trabalhador não se reconhece em relação ao mundo, nem em relação aos demais indivíduos, nem em relação a si mesmo.

Os primeiros elementos da teoria da alienação em Marx estão postos claramente neste pequeno texto. A política democrático burguesa não é capaz de resolver as mazelas do capitalismo, porque o humano não é possível nesta sociedade. Apenas em outra forma societária, na qual as relações entre os indivíduos sejam mediadas pelo trabalho livre e emancipado, na qual os indivíduos sejam autônomos e o Estado democrático burguês não passe de uma matéria histórica passada, é que a política torna-se instrumento da emancipação humana. Uma sociedade assim só pode ser conquistada com a ação consciente dos homens para a superação das relações sociais capitalistas, que só pode vir através de uma revolução, ou, do declínio da velha sociedade capitalista e do velho poder político burguês.

Marx entende que todas as revoluções têm sua origem no isolamento do indivíduo em relação à comunidade. Porém, alerta que nem toda revolução se afigura da mesma forma: uma revolução que exploda a partir do desesperado isolamento do homem da comunidade política será inevitavelmente uma revolução das classes privadas de influência e poder político contra as classes detentoras dele. Portanto, tal revolução, embora constitua um avanço importante na conquista de direitos humanos essenciais, é parcial e limitada. É o caso, por exemplo, da 
Revolução Francesa, em que o Estado que se pretendia libertador tornou-se prisioneiro de suas próprias vicissitudes.

Por outro lado, uma revolução que seja social provém do sufocante isolamento do homem de sua própria essência, na explicação de Marx:

\begin{abstract}
Uma revolução social se situa do ponto de vista da totalidade porque - mesmo que aconteça apenas em um distrito industrial - ela é um protesto do homem contra a vida desumanizada, porque parte do ponto de vista do indivíduo singular real, porque a comunidade, contra cuja separação o indivíduo reage, é a verdadeira comunidade do homem, é a essência humana. (Marx, 2010, p. 76).
\end{abstract}

A diferença decisiva está no fato de que, numa revolução política, não há superação do Estado como totalidade abstrata baseada na separação entre indivíduo e sociedade civil; ao passo que em uma revolução social a libertação pela qual se luta é a da essência humana cativa nos meandros do intelecto político incapaz de alcançá-la. Ao libertar-se politicamente das condições de classe, o homem não se liberta das contraditórias relações políticas, apenas conquista uma certa liberdade de escolha. Ao libertar-se humanamente, supera as relações formais e a contradição entre a vida coletiva e a liberdade individual ${ }^{3}$.

Para Marx toda revolução é necessariamente política e social, porque é uma manifestação de superação da velha ordem. "Toda revolução dissolve a velha sociedade; nesse sentido é social. Toda revolução derruba o velho poder; nesse sentido é política". (Marx, 2010, p. 77). Porém, quando uma revolução pára na dissolução do velho poder político, ela é parcial, insuficiente e não efetiva a liberdade humana, não promove o reencontro do homem com sua essência.

O duplo caráter da política, em Marx, é bem claro no texto aqui analisado. Por um lado, como mantenedora de relações sociais formais que não se efetivam objetivamente, a política mantém o isolamento do homem de sua essência, posto que não seja capaz de efetivar a igualdade a não ser na forma de um direito abstrato. Por outro lado, a transformação da sociedade é inevitavelmente um ato político, porque exige do processo revolucionário a dissolução do velho poder. Ao mesmo tempo em que afirma as desigualdades, a política é um importante instrumento revolucionário.

\footnotetext{
3 Em outro texto, Sobre a Questão Judaica, Marx aprofunda a análise sobre o tema da emancipação, demonstrando que a emancipação política, embora parcial e limitada, é um avanço importante. Porém, ela não é suficiente, porque não emancipa o ser humano das relações desumanas, ela muda apenas a forma como a dominação se efetiva. O homem torna-se livre para escolher o seu feitor, mas ainda há feitores.
} 
Contudo, se é parafrásico ou absurdo uma revolução social com alma política, é racional, ao contrário, uma revolução política com alma social. A revolução em geral - a derrocada do poder existente e a dissolução das velhas relações - é um ato político. Por isso, o socialismo não pode efetivar-se sem revolução. (Marx, 2010, p. 78).

Para Marx, a destruição e dissolução da velha ordem social não podem prescindir da política. A grande diferença entre esta perspectiva e a revolução política é que, tão logo o objetivo do socialismo surgir no horizonte, logo que ele comece a organizar uma sociedade mais livre, os andrajos da política devem ser abandonados. A política é negativa para Marx porque não tem limites, quer melhorar aquilo que não pode ser melhorado; quer resolver contradições formalmente (na lei), mas não é possível que as profundas contradições do capital sejam resolvidas por leis. A política é negativa, então, também porque ela não é feita pela totalidade da sociedade, mas por políticos que, no mais das vezes, são incapazes. Quando a sociedade não é capaz de se autodeterminar, e a política passa a considerar os problemas sociais como falhas administrativas, então a direção e a justificativa para a ineficiência e permanência das mazelas passa a ser moral. Em se tornando moral, assimila também a condição de ser pragmatista, resolvendo situações pontuais, sem compreender os fundamentos dos problemas. Com isto, a política torna-se engodo e estranhamento.

A emancipação humana só pode ser conquistada pelos indivíduos organizados em torno do ideal de transformação radical da sociedade. A política precisa ser combatida com a política. É com a política social que se combate o Estado burguês. Porém, não com a política baseada na vontade, porque esta é uma forma de política que não se constitui como antítese do intelecto político moderno. A positividade da política em Marx está na negação do Estado burguês para se chegar até a oposição às ações pontuais, à postura contrária e de denúncia do formalismo político e à conscientização da classe trabalhadora sobre as condições concretas de alienação e exploração do trabalho. A Revolução é também um ato político.

Referências

CHAGAS, Eduardo. A Comunidade Política: a teoria do estado no jovem Marx. Ijuí: Editora Unijuí, 1998.

KONDER, Leandro. Marx: vida e obra. Rio de Janeiro: Paz e Terra, 1981.

\begin{tabular}{|l|l|l|l|l|}
\hline Qenista Dialectus & Ano 2 & n.5 & Agosto - Dezembro 2014 & p. 80 - 96 \\
\hline
\end{tabular}


MARX, Karl. Glosas Críticas Marginais ao Artigo "O Rei da Prússia e a Reforma Social”, de um prussiano. São Paulo: Expressão Popular, 2010.

TONET, Ivo. A Propósito de "Glosas Críticas". IN: MARX, Karl. Glosas Críticas

Marginais ao Artigo "O Rei da Prússia e a Reforma Social”, de um prussiano. São Paulo:

Expressão Popular, 2010, pp. 7-35 